\title{
Effects of lateral connectivity on zooplankton community structure in floodplain lakes
}

\author{
Anna Goździejewska - Katarzyna Glińska-Lewczuk • Krystian Obolewski • \\ Mirosław Grzybowski • Roman Kujawa · Sylwia Lew • \\ Magdalena Grabowska
}

Received: 23 November 2015/Revised: 22 February 2016/Accepted: 28 February 2016/Published online: 8 March 2016

(C) The Author(s) 2016. This article is published with open access at Springerlink.com

\begin{abstract}
Hydrological conditions are responsible for the changes in lateral connectivity between the main river channel and the floodplain lakes, a factor controlling zooplankton abundance and diversity. We tested the hypothesis that the degree of connectivity between the aquatic habitats and the river channel governs the zooplankton densities and community structure. Abundances, community composition and species diversity of zooplankton were analysed against the gradient of lakes' connectivity and the water
\end{abstract}

Guest editors: Pierluigi Viaroli, Marco Bartoli \& Jan Vymazal / Wetlands Biodiversity and Processes: Tools for Management and Conservation

Electronic supplementary material The online version of this article (doi:10.1007/s10750-016-2724-8) contains supplementary material, which is available to authorized users.

\footnotetext{
A. Goździejewska $(\bowtie) \cdot$ M. Grzybowski

Department of Tourism, Recreation and Ecology, University of Warmia and Mazury in Olsztyn, Olsztyn, Poland

e-mail: gozdzik@uwm.edu.pl

K. Glińska-Lewczuk

Department of Water Resources, Climatology and

Environmental Management, University of Warmia and

Mazury in Olsztyn, Olsztyn, Poland

e-mail:kaga@uwm.edu.pl

K. Obolewski

Department of Hydrobiology, University of Kazimierz

Wielki in Bydgoszcz, Bydgoszcz, Poland

e-mail: obolewsk@ukw.edu.pl
}

quality parameters under a natural flood pulse in the Biebrza River (North-Eastern Poland). Our findings revealed that the water level fluctuations directly affect the availability of nutrients, aeration, what in turn controls the densities and biovolumes of zooplankton communities. Along with the increase in the lake isolation, the taxonomic diversity of zooplankton decreased, while the eudomination of taxa indicative of advanced trophy (Rotifera) was observed. Qualitative parameters, as number of species, diversity and richness, were significantly higher at mean water levels, which supports the intermediate disturbance hypothesis. The sensitivity of the zooplankton community to variable hydrological conditions and lateral connectivity gradient demonstrates its potential as an unexploited indicator of any habitat changes in the aquatic ecosystems.

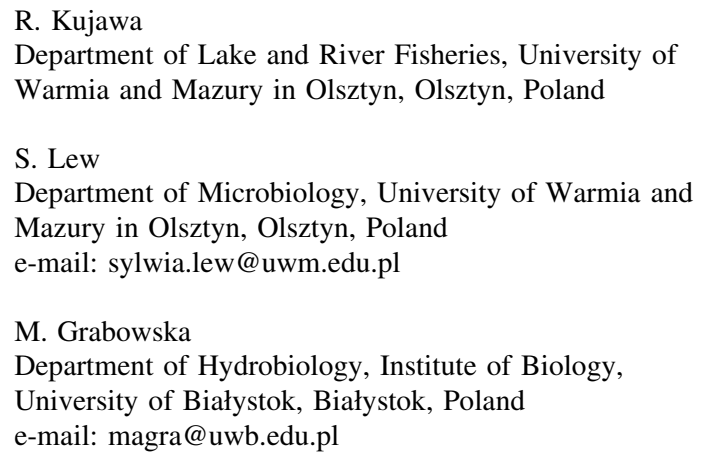


Keywords Zooplankton · Floodplain lakes · Hydrological connectivity $\cdot$ Flooding

\section{Introduction}

Floodplain lakes play numerous roles among mosaics of the riverine ecosystems; however, their function as biodiversity hotspots has gained some degree of attention due to significant and global loss of natural river-floodplain systems. In recent centuries, many rivers have been strongly transformed as a result of an intensive engineering (Buijse et al., 2002), and their potential for biodiversity development has been seriously impoverished (Dembowska, 2015). Unlike many transformed rivers, the Biebrza River (NorthEastern Poland) belongs to the last remnant European watercourses which became unmodified. The floodplain of the Biebrza River is internationally recognised as a reference area for the restoration of deteriorated wetlands (Wassen et al., 2002). Its unique feature is quite a complicated drainage system, consisting of a complex network of inundation fields and storage areas. Until date, the river has a natural, untransformed floodplain and an undisturbed hydrological regime, allowing for the development of mosaics of aquatic habitats, which differed from the parent river by a degree of lateral connectivity. According to Amoros \& Roux (1988), they represent the following types which differed by the water residence time (water age): eupotamic - the main river channel; parapotamiclotic side-channels (bypasses) with flowing water lotic habitats; plesiopotamic - semi-lotic abandoned meanders, permanently connected to the river by a downstream arm, as well as paleopotamic-paleopotamic side-channels and depressions filled with stagnant water and isolated from the river, except in cases of flooding (lentic habitats).

Differences in hydrological connectivity between floodplain lakes and the river are a key factor that influences abiotic (flow rate, temperature, oxygen concentrations and water transparency) and biotic (species composition of plant and animal, food and habitat availability and species interaction) features of the ecosystems (Winemiller et al., 2000; Gruberts et al., 2007; Grabowska et al., 2014; Kufel \& Lesniczuk, 2014). These habitats also have associated characteristic assemblages of zooplankton, thereby, tolerating a broad range of variability of the environmental factors: stenotopic species, as well as species having proper adaptation mechanisms, for example, having proper adaptation mechanism to periodical deficits of water (Schröder, 2001; Havel et al., 2000). Most probably, the hydrologic regime is the factor that most strongly diversifies the living conditions of the plankton fauna (Illyová, 2006; Pithart et al., 2007; Havel et al., 2000; Pociecha \& Wilk-Wozniak, 2006). In accordance with the 'intermediate disturbance hypothesis (IDH)' (Connell, 1979), higher species diversity is expected in water bodies that connect with intermediate frequency (Amoros \& Bornette, 2002). In that case, the scouring effect of water velocity is likely to disturb the aquatic vegetation and, thereby, reduce interspecific competition, allowing the cooccurrence of the maximum number of the plant species. However, this maximum number also depends on: (1) the trophic status of the water body, (2) propagule inputs and (3) the availability of regeneration niches required for the recruitment of the colonising species.

In light of the above, we hypothetized that zooplankton assemblages, as well as the hydrobionts that inhabit the floodplain aquatic ecosystems, constitute an important element of the food chain, and are effective indicators of the trophic conditions. Zooplankton is the first link of consumers in the trophic chain of aquatic ecosystems. Simultaneously, the zooplankton itself is a food for larvae and fry of most fish species (Medeiros \& Arthington, 2008). To understand the ecological function of natural floodplain lakes, in order to select in the future a proper method for their protection, adequate knowledge is required for all the biocoenosis elements, including zooplankton. Thus, the main objective of the paper was a question of how zooplankton communities can face the intrinsic variability of lowland meandering river ecosystem. The study was also aimed at providing answers to the following questions: (1) how plankton communities can establish and persist with a stable structure in running waters and in their lateral water bodies? (2) How lateral connectivity of aquatic ecosystems and water exchange are responsible for species diffusion and distribution? (3) Which factors are structuring the community? And last but not the least, (4) Can the 'intermediate disturbance hypothesis' (sensu Connell, 1979) be applied in this study case. 


\section{Materials and methods}

Location of the study area and objects

The Biebrza is a medium-sized low-gradient river, famous for the natural outstanding values of its vast floodplain area covering $1,950 \mathrm{~km}^{2}$. In spite of its extensive catchment draining in the mid-1970s, Biebrza's floodplain escaped alteration, and its natural landscape and flood-pulse pattern have been almost entirely preserved and have never been dammed, diverted, regulated or embanked. Excluding a 10-kmlong section, the river is part of the Biebrza National Park, and it is protected under the Ramsar Convention. River channel crosses boggy meadows and marshes, meandering considerably and forming a large number of old riverbeds and water bodies in different stages of succession.

The hydrological regime of Biebrza River in its middle course shows a distinct natural flood pulse within the range of $264 \mathrm{~cm}$ (Fig. 1B), with significant irregularity of flows (Chormański et al., 2011). The river is characterised by long-term spring floods, when the narrow river swells to form a vast shallow impoundment, locally up to $1 \mathrm{~km}$ in width, which lasts for several months. The average multi-annual flow (1984-2013) measured at the gauge in Osowiec amounts to $22.78 \mathrm{~m}^{3} \mathrm{~s}^{-1}$, in the range of 3.08-360.00 $\mathrm{m}^{3} \mathrm{~s}^{-1}$ (Grabowska et al., 2014). The periods of overbank flooding was calculated using the discharge rating curve method.

The study was carried out in 10 floodplain lakes, and the main river channel of the Biebrza River (Fig. 1). The lakes were selected from among a diversity of former meanders located within the Middle Biebrza Basin, along a $20 \mathrm{~km}$ section of the river channel. The lakes differ by lateral connectivity gradients, according to Amoros \& Roux (1988) and water retention patterns, and thus, were classified as follows (Fig. 1):

- Eupotamic-flowing water: the Biebrza River;

- Parapotamic-lotic side-channels: Stara Rzeka (STR), Mostek (MOS) and Czerwony Domek (CZD);

- Plesiopotamic - semi-lotic lakes, connected to the river by a downstream arm: Bocianie Gniazdo (BOC), Klewianka (KLE), Tur (TUR) and Glinki (GLI);

- Paleopotamic-lentic lakes: Budne (BUD), Bednarka (BED) and Fosa (FOS).

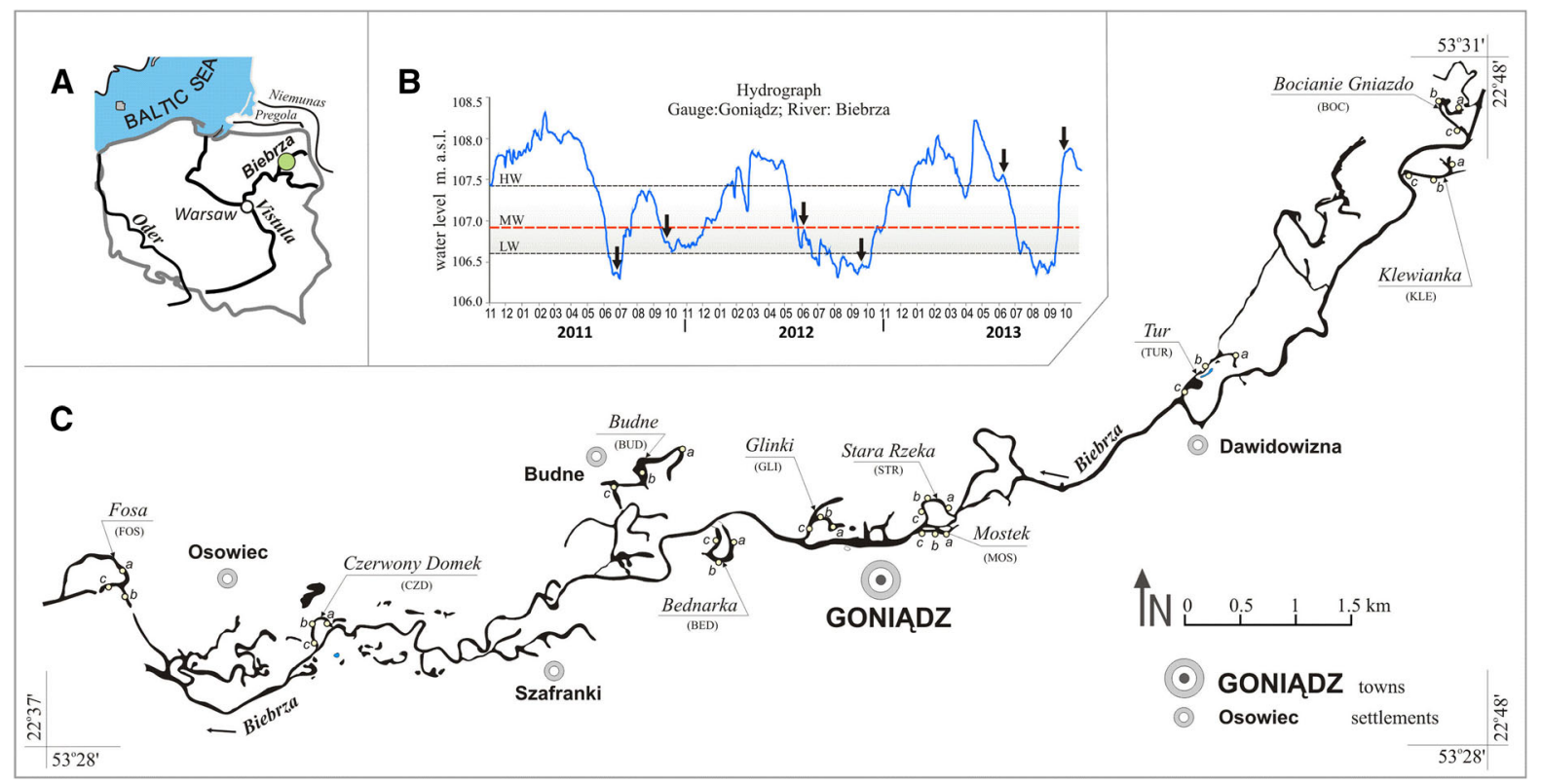

Fig. 1 Location of study sites in the Middle Basin of the Biebrza River on the background of Poland (A) and the Biebrza River catchment (B) 
In the present paper, we equate lateral hydrological connectivity to the permanent and episodic links between the main river channel and the water bodies lying on the alluvial floodplain (Amoros \& Roux, 1988; Baranyi et al., 2002), in relation to the mean water level in the gauge at Osowiec.

Sampling and analytical procedure

Samples of zooplankton were taken twice a year, in the months of June and September of each year of the study (2011-2013). Sampling regime was subjected to hydrological conditions, in particular, seasons with high and low water table. Samplings took place on a boat at three sites (upstream arm, downstream arm and the middle section), along each of the ten floodplain lakes, which gave, in total, thirty sampling sites, also from the Biebrza River channel (two sites). Samples of zooplankton with volumes of 20 litres were collected in triplicates from the subsurface layer $(30-50 \mathrm{~cm})$, and from the central parts of floodplain lakes. Thereafter, the samples were concentrated on plankton net with a mesh size of $30 \mu \mathrm{m}$, fixed with Lugol solution and preserved with $4 \%$ formalin solution.

Zooplankton was identified up to the lowest possible taxon (apart from juvenile stages of Copepoda), according to the methodology of von Flössner (1972), Koste (1978), Kiefer \& Fryer (1978) and Sterble \& Krauter (1978). Quantitative analysis consisted in the evaluation of abundance, using a Sedgewick-Rafter chamber, and determination of the zooplankton's biomass, according to the methodology of RuttnerKolisko (1977), Ejsmont-Karabin (1998) and Bottrell et al. (1976).

Diversification of the zooplankton's qualitative structure was evaluated in regard to the dominating structure (D) (Kasprzak \& Niedbała, 1981), species abundance $(d)$, diversity $\left(H^{\prime}\right)$ and evenness $\left(J^{\prime}\right)$. Based on the features of the Rotifera groups by Karabin (1985), an attempt was made to evaluate trophy of waters of the individual floodplain lake types. Based on the environmental preferences of zooplankton species (Duggan, 2001; Radwan \& Bielańska-Grajner, 2001; Radwan et al., 2004; Rybak \& Błędzki, 2010), the influence of floodplain lakes connectivity on the formation of eurytopic, psammonic and the littoral associations were defined.

Zooplankton taxa were expressed in abundance, and only those taxa with a share of, at least $2 \%$ in a given station, were retained for further ordination analysis. The diversity indices $\left(H^{\prime}\right.$ and $\left.J^{\prime}\right)$ were calculated with the use of Past v.2.17c software (Hammer et al., 2001). Inventory of aquatic macrophytes and assessment of their coverage percentage was made using the BraunBlanquet scale (Braun-Blanquet, 1964).

Water for chemical analyses was sampled simultaneously with the zooplankton sampling. In situ measurements of dissolved oxygen (DO), $\mathrm{pH}$, electrical conductivity (SEC), turbidity, as well as chlorophyll$a$ and cyanobacteria (Phycocyanin Blue-Green Algae Sensor, BGA) concentrations were performed, using the YSI 6600R2 $2^{\mathrm{TM}}$ calibrated multiprobe (USA). Water transparency was measured with the Secchi's disc. The concentrations of phosphates, nitrates, nitrites and ammonium ions were determined in a laboratory, using standard analytical methods (APHA, 1999). Total organic carbon (TOC) and dissolved organic carbon (DOC) analyses were conducted by high-temperature combustion (HTC) (Shimadzu TOC 5000 analyzer, Japan) and performed according to the protocol described by Dunalska et al. (2012).

\section{Statistical procedures}

To assess the general differences between floodplain lakes, physico-chemical parameters of water and zooplankton abundance, a non-parametric analysis of variance was applied. The results were processed by ANOVA using the non-parametric Kruskal-Wallis and Dunn's tests, to determine significant differences in zooplankton density and biomass between the analysed types of floodplain lakes $(P \leq 0.05)$. Correlation coefficients were calculated with the use of Spearman ranks $(P \leq 0.05)$.

The response of zooplankton communities to the environmental variables was analysed with CANOCO 4.5 for Windows (ter Braak \& Šmilauer, 2002) using multivariate statistical procedures. Redundancy analysis (RDA) was used because the length of the gradient in the dataset checked in DCA ordination was CA 1.64 SD, which indicated a linear variation. RDA is a direct gradient analysis that summarises the relationship between zooplankton species and environmental parameters. Redundant variables were removed by a step-wise regression (forward selection) with Monte Carlo permutation tests. The dataset was $\log$ transformed $[\log (n+1)]$ and centred on species, as this is obligatory for the constrained linear methods. 


\section{Results}

Environmental characteristics

During the whole study period (2011-2013), the floodplain lakes were under the natural flood pulse of the Biebrza River with its typical irregularity of flows. The water levels fluctuated within the range of $264 \mathrm{~cm}$ (Fig. 1B). The share of days exceeding bankfull level (>HWL), which is also referred to potamophase, in 2011, 2012 and 2013, accounted for 42,35 and $48 \%$, respectively. Stages below the mean low water level $(<\mathrm{MLW})$ referred to limnophase, in 2011 lasted for $8 \%$ of the year, in 2012-23\%, while in 2013-19\%. Prolonged spring floods promoted hydraulic and ecological connectivity among all water ecosystems in the floodplain.

The studied floodplain lakes were diverse in terms of any environmental conditions, such as water temperature, transparency, dissolved oxygen and conductivity (Table 1, 2). Dissolved oxygen (DO) was significantly higher and more stable in the parapotamic lakes $\left(7.45 \pm 1.54 \mathrm{mg} \mathrm{l}^{-1}\right)$ than in plesiopotamic $\left(6.51 \pm 2.12 \mathrm{mg} \mathrm{l}^{-1}\right)$ and paleopotamic habitats $\left(6.13 \pm 2.31 \mathrm{mg} \mathrm{l}^{-1}\right)$. Lateral contact with well-aerated river water protects parapotamic and plesiopotamic lakes against severe oxygen deficits. Lower values of conductivity, as a measure of mineral compound concentrations, represented parapotamic habitats, while higher values were associated with paleopotamic lakes. The $\mathrm{pH}$ of the water was slightly alkaline $(\mathrm{pH} 7.77 \pm 0.27)$ and decreased significantly when water levels were high, particularly in parapotamic water bodies $(r=-0.62 ; P=0.001)$. High concentrations of suspended solids in paleopotamic habitats reduced water transparency to $1.1 \pm 0.3 \mathrm{~m}$. In plesiopotamic and parapotamic lakes, Secchi's disc visibility was significantly higher at $1.5 \pm 0.6$ and $2.0 \pm 0.9 \mathrm{~m}$, respectively. The overall productivity of ecosystems was related to the concentrations of chlorophyll- $a$, which in paleopotamic and plesiopotamic lakes, was twice as much $(\sim 17.50$ $\left.\mu \mathrm{g}^{-1}\right)$ as in parapotamic habitats $(8.04 \pm 4.03$ $\left.\mu \mathrm{g}^{-1}\right)$ or in the river $\left(7.31 \pm 0.80 \mu \mathrm{g} \mathrm{l}^{-1}\right)$. Floodplain lakes were generally abundant in organic matter, whose average content was estimated at $12.59 \pm 4.64 \mathrm{mg}$ of TOC per $1^{-1}$ with a significant share of DOC $\left(10.50 \pm 3.18 \mathrm{mg} \mathrm{l}^{-1}\right)$. In addition to an autogenic source of organic matter, the accumulation of humic compounds and decomposed organic matter from adjacent peatlands significantly contributed to an increase in DOC in the paleopotamic lakes $\left(48.92 \pm 21.50 \mathrm{mg}^{-1}\right)$. More detailed description of temperature, dissolved oxygen, chlorophyll- $a$, and nutrients recorded can be found in publication by Grabowska et al. (2014). Instead, we emphasised description of the environmental conditions and planktonic fauna abundance and species richness as a function of hydrological and hydrochemical variables. Physicochemical determinants of zooplankton community structure have been indicated by redundancy analysis (RDA) and described in the discussion section.

\section{Zooplankton structure}

A total of 185 taxa were identified in the zooplankton composition of the floodplain lakes and in the Biebrza River, including 137 Rotifera, 28 Cladocera, 7 Copepoda and 13 Protozoa. Rotifera were represented by 17 families, from which Lecanidae (28 species) and Trichocercidae ( 25 species) were characterised as the biggest diversity. On the other hand, the prevailing species, species in the zooplankton structure belonged to Brachionidae and Synchaetidae families (Anuraeopsis fissa, $K$. cochlearis, $K$. cochlearis var. tecta, Polyarthra longiremis). In the total zooplankton abundance, Rotifera constituted about $75 \%$ in parapotamic to $93 \%$ in plesiopotamic lakes, on the average (Appendix in supplementary material). Crustaceans occurred scarcely and irregularly. Alona (8 species) and Pleuroxus genus (4 species) were the ones mostly represented, while the most numerous populations developed within Ch. sphaericus and Ceriodaphnia quadrangula species. Larval stagesnauplii and copepodits of Copepoda-were constant components of the structure (100\% frequency). In the general zooplankton biomass, Crustacea constituted about $20 \%$ in the plesiopotamic to $72 \%$ in the parapotamic lakes (Appendix in supplementary material), on the average. Protozoa were represented by 13 taxa, among which amoebae of Arcella and Difflugia genera prevailed.

Influence of hydrological connectivity

Quantitative parameters of zooplankton of paleopotamic water bodies were significantly different from those of lotic character $(P \leq 0.05)$.

In the studied floodplain lakes, in total, 133 taxa of zooplankton were identified, including 98 Rotifera, 23 


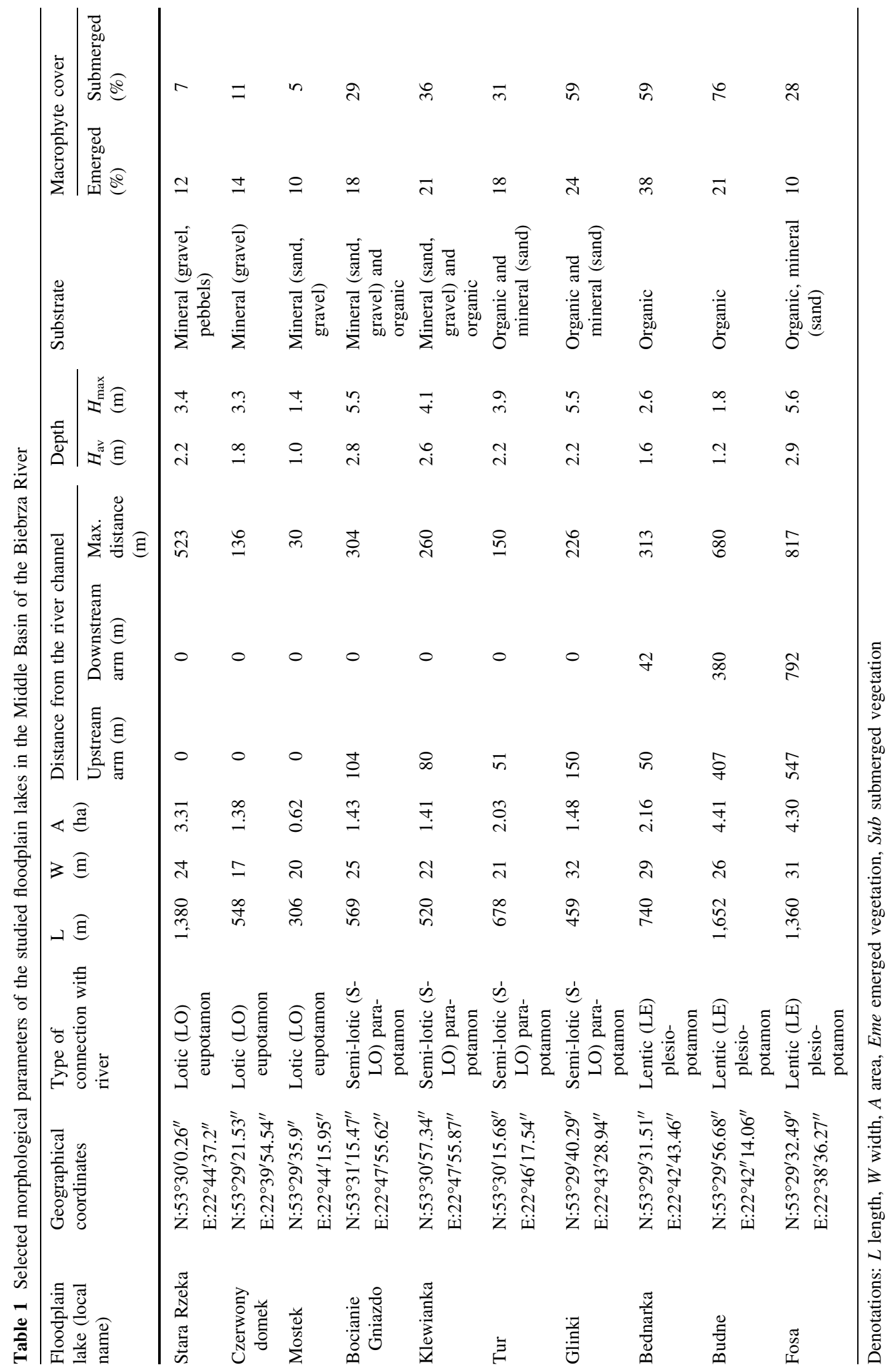




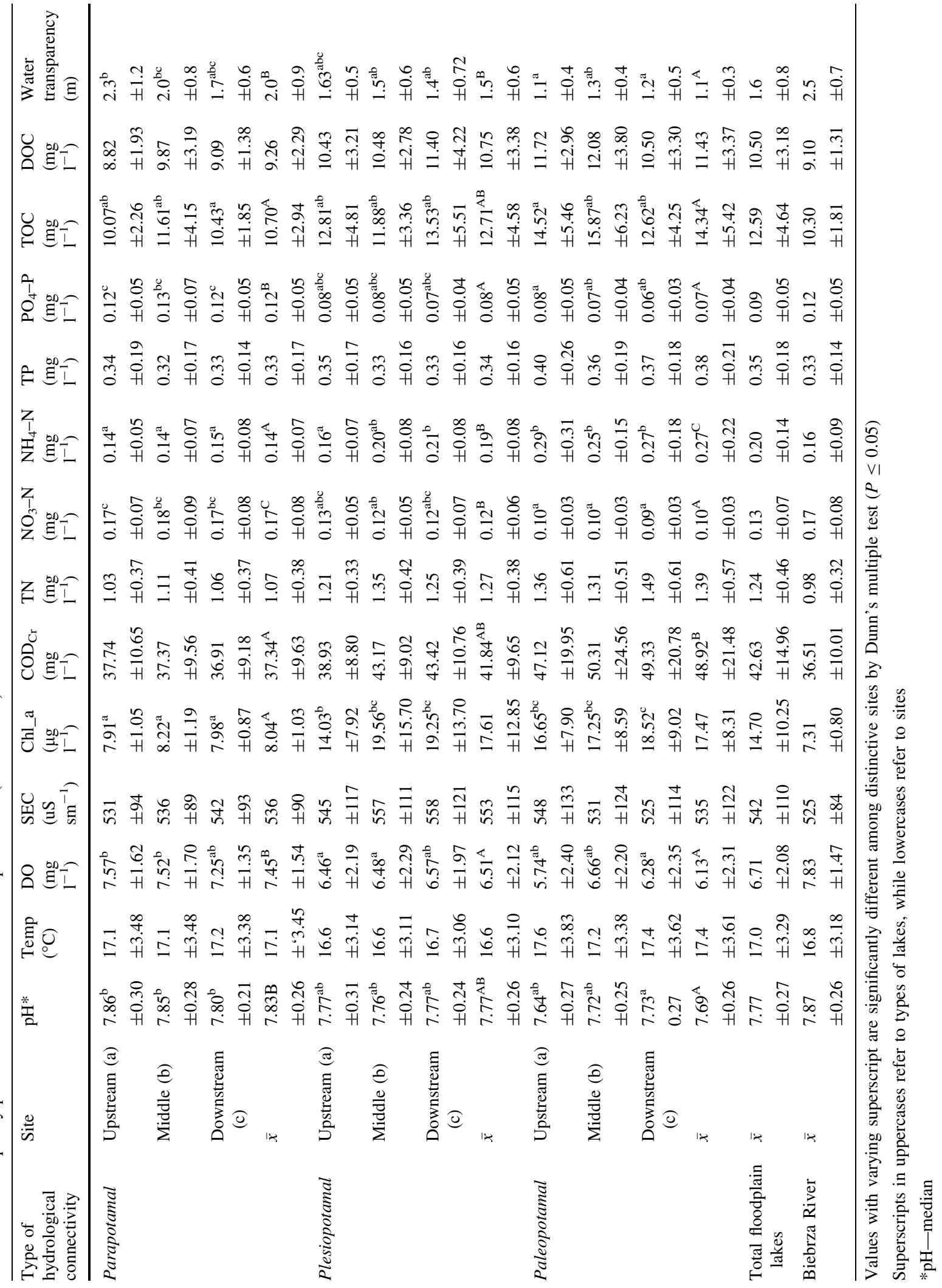


Table 3 Shares of ecological groups (\%) in the zooplankton structure of the individual floodplain lake types, in selected sites: Aupstream, B-middle, $\mathrm{C}$-downstream

\begin{tabular}{|c|c|c|c|c|c|c|c|c|c|c|c|c|c|}
\hline \multirow[t]{2}{*}{ Ecological groups/Site } & \multirow[t]{2}{*}{ Biebrza River } & \multicolumn{4}{|c|}{ Parapotamal } & \multicolumn{4}{|c|}{ Plesiopotamal } & \multicolumn{4}{|c|}{ Paleopotamal } \\
\hline & & A & B & $\mathrm{C}$ & $\bar{x}$ & A & B & $\mathrm{C}$ & $\bar{x}$ & A & B & $\mathrm{C}$ & $\bar{x}$ \\
\hline Eurytopic & 77.0 & 87.2 & 63.5 & 71.8 & 74.9 & 92.5 & 94.0 & 92.5 & 93.0 & 97.3 & 95.7 & 96.1 & 96.3 \\
\hline Littoral, vegetation & 8.0 & 4.2 & 9.6 & 7.8 & 7.4 & 5.0 & 4.8 & 6.2 & 5.3 & 1.5 & 2.5 & 3.0 & 2.3 \\
\hline Psammonic, peatlands, marshes & 15.0 & 8.6 & 27.0 & 20.4 & 17.7 & 2.5 & 1.1 & 1.4 & 1.7 & 1.3 & 1.9 & 0.9 & 1.3 \\
\hline
\end{tabular}
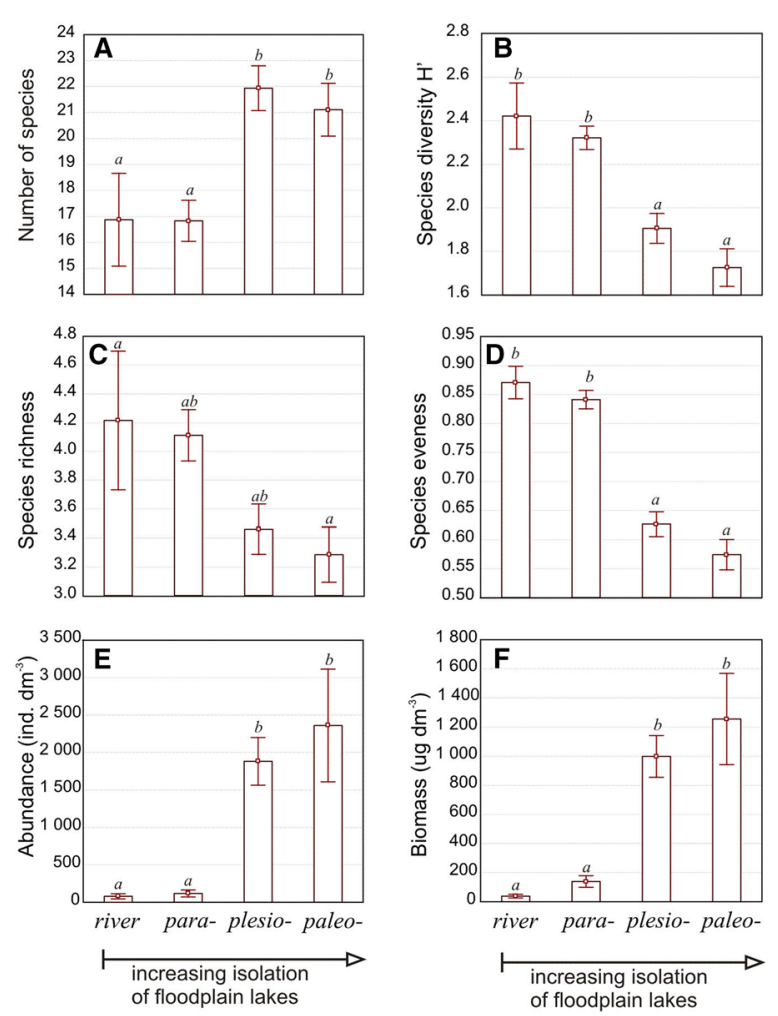
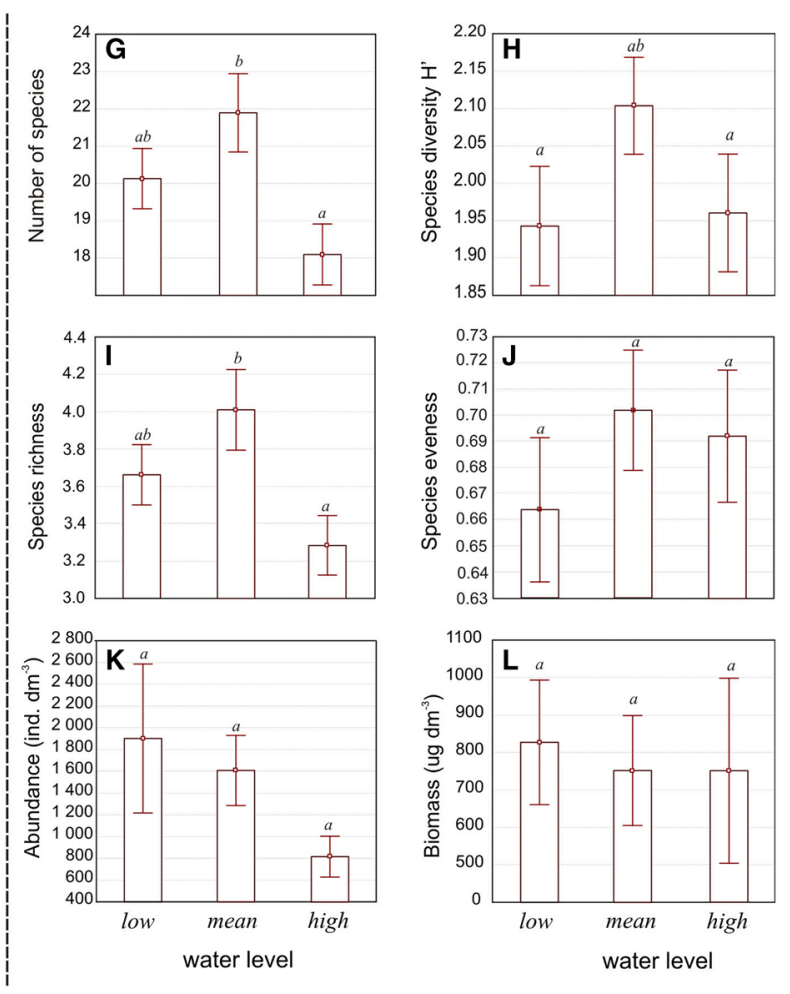

Fig. 2 Number of species (ind.) (A, G), species diversity $\mathrm{H}^{\prime}(\mathbf{B}, \mathbf{H})$, species richness $(\mathbf{C}, \mathbf{I})$, species evenness $(\mathbf{D}, \mathbf{J})$, abundance (ind. $\left.\mathrm{dm}^{-3}\right)(\mathbf{E}, \mathbf{K})$ and biomass $\left(\mu \mathrm{g} \mathrm{dm}{ }^{-3}\right)(\mathbf{F}, \mathbf{L})$ of zooplankton in type of floodplain lake and in hydrological condition (water level)

Crustacea and 12 Protozoa. The lowest number of taxa occurred in the downstream (79), the highest-in the middle part (100). As many as 56 species were identified in the river midstream. Psammonic-phytophilic (mean 18\%, max. 27\%) and littoral (mean 7\%, max. $10 \%$ ) (Table 3) associations were characterised by the highest qualitative and quantitative shares, represented by numerous species of Lecane, Cephalodella and Trichocerca genera. In parapotamic lakes, a high diversity of littoral Cladocera was found, particularly from Alona and Pleuroxus genera
(Table 3). Maximum shares of the aforementioned environmental groups were found in the middle part of the meanders (Table 3).

Taxonomic diversity of zooplankton of the analysed floodplain lakes decreased with increasing isolation from the river main stream (Figs. 2B, C). The highest values of the diversity index $\left(H^{\prime}\right)$ and the species abundance index $(d)$ were found in lotic lakes (mean $H^{\prime}=2.32$ and $d=4.1$; max. $H^{\prime}=3.2$ and $d=8.0$ ), while the middle part of the meander was the most taxonomically diversified (mean $H^{\prime}=2.45$ and 
$d=4.5)$. In the river, both parameters had similar levels (mean $H^{\prime}=2.42$ and $d=4.2$; max. $H^{\prime}=2.9$ and $d=6.1$ ). A high diversification of zooplankton in open-type floodplain lakes, with simultaneously high values of the evenness index (mean $J^{\prime}=0.896$ downstream, max. $J^{\prime}=0.978$ ) (Table 3; Fig. 2D) indicates a uniform share of the species in the biocoenosis.

Among the values of indices of taxonomic diversity features discussed above and the quantitative parameters of zooplankton of the river and the meandering channels, no statistically significant differences at the level of $P<0.05$ (Fig. 2A-F) were found.

Zooplankton of plesiopotamic fluvial lakes was represented by 147 taxa, including 115 Rotifera, 21 Crustacea and 11 Protozoa, while in the cutoff meander, the highest number of species (115), in total, was found. The highest abundances of zooplankton were stated in the middle parts of parapotamic lakes (mean 3,296 ind. $\mathrm{dm}^{-3}$ ), among which rotifers constituted $95 \%$ (mean 3,127 ind. $\mathrm{dm}^{-3}$ ). Both parameters discussed above were significantly different (post hoc Dunn's test, ANOVA; $P \leq 0.05$ ) in comparison with parapotamic meanders and Biebrza River midstream (Fig. 2B). In the qualitative structure, dominated Rotifera species: A. fissa (12\%), K. cochlearis (20\%), $K$. cochlearis var. tecta (11\%), P. longiremis (23\%) and Filinia longiseta $(6 \%)$. The biodiversity indicators of the plesiopotamic fluvial lakes were significantly lower $(P \leq 0.05)$ in relation to meandering channels and amounted to, on average: $H^{\prime}=1.90, d=3.5$; max. $H^{\prime}=3.10, d=6.9$, in the closed meander. The strong domination of the Rotifera species mentioned above, particularly evident in the middle part of meanders, resulted to a decrease in the value of the evenness index (mean $J^{\prime}=0.599$, max. $\left.J^{\prime}=0.970\right)$.

The amount of the determined taxa in the paleopotamic floodplain lakes was high and close to that of the plesiopotamic lakes (no significant differences at the level of $P \leq 0.05$ ). Almost all biocoenosis was dominated quantitatively by Rotifera: A. fissa (658-2,077 ind. $\left.\mathrm{dm}^{-3}, 22-55 \%\right), P$. longiremis (368-668 ind $\left.\mathrm{dm}^{-3}, 10-23 \%\right)$ and $K$. cochlearis (5-21\%). Particularly, there are Populations of Ch. sphaericus and Ceriodaphnia quadrangula that are abundantly developed. Juvenile stages of Copepoda nauplii (166 ind. $\mathrm{dm}^{-3}$ ) (Appendix in supplementary material) were represented in very high numbers. The structure of paleopotamic lake zooplankton, estimated with ecological indices of diversity and species evenness, was the least diversified and the scantiest in relation to the other fluvial lake types (mean $H^{\prime}=1.73, d=3.3, \quad J^{\prime}=0.574 ; \max H^{\prime}=2.95$, $d=6.8, J^{\prime}=0.875$ ) (Appendix in supplementary material; Fig. 2B-D).

\section{Influence of water level}

Statistically significant differences $(P \leq 0.05)$ between the three analysed water levels are not always connected to the same seasons, occurred only in the case of qualitative indices, that is, the number of species $(N)$ and the species abundance $(d)$ (Fig. 2G, I). The highest values of these parameters were found during medium water levels $\left(N_{\text {mean }}=22, N_{\text {max }}=50\right.$; $\left.d_{\text {mean }}=4.0, d_{\max }=8.0\right)$, and the lowest onesduring high water levels $\left(N_{\text {mean }}=19, N_{\max }=40\right.$; $d_{\text {mean }}=3.5, d_{\max }=7.1$ ).

The water level did not differentiate significantly the shares of the individual taxa and environmental groups in the general abundance of zooplankton. It did not affect the diversity of the abundance value and biomass (Fig. 2K, L) either.

Primary gradients affecting zooplankton community

The RDA summarises the relations between the zooplankton species composition and environmental variables (Fig. 3A). The results of the ordination showed that the eigenvalues of the first $\left(\lambda_{\mathrm{RDA} 1}=0.256\right)$ and second $\left(\lambda_{\mathrm{RDA} 2}=0.044\right) \mathrm{RDA}$ axes accounted for $75.4 \%$ of the variation in the environmental data. Twelve variable input were retained as significant contributors (Table 4) to the model, and all canonical axes were significant (Monte Carlo test, $P=0.002$ ). The hydrological set of variables (including isolation gradient and water level variability) accounted for $\lambda_{1}=15 \%$ of species variability. Trophic variables $\left(\mathrm{TN}, \mathrm{NO}_{3}-\mathrm{N}, \mathrm{TP}, \mathrm{PO}_{4}-\mathrm{P}\right.$ and chlorophyll- $a$ and BGA) explained as much as $21 \%$ of the variance, while physical and chemical variables, including $\mathrm{SEC}, \mathrm{DO}, \mathrm{COD}_{\mathrm{Cr}}$ and $\mathrm{DOC}$ explained in total $14 \%$.

Most of the quantitatively significant zooplankton species (share $>2 \%$ ) subjected to the analysis were connected to factors indicating a presence of organic matter in the water, dissolved and suspended $\left(\mathrm{COD}_{\mathrm{Cr}}\right.$, 
A

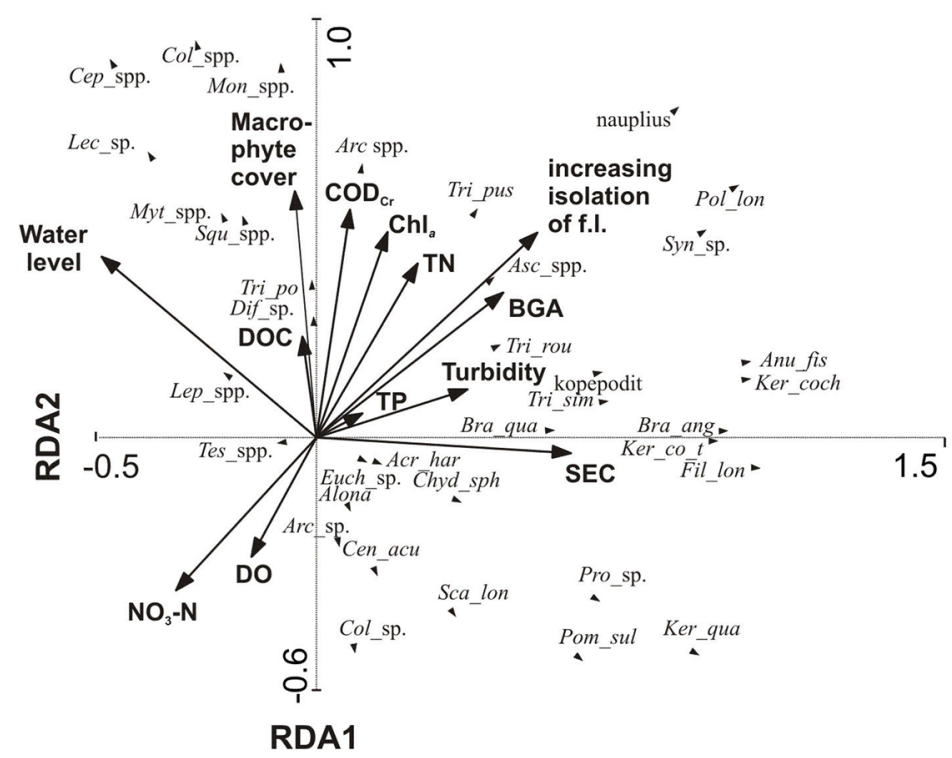

Total

\begin{tabular}{|c|c|c|c|}
\hline Axes & RDA1 & RDA2 & lariance \\
\hline Eigenvalues : & 0.115 & 0.042 & 1.000 \\
\hline Species - envir. correl: & 0.775 & 0.710 & \\
\hline Cumulative $\%$ variance & & & \\
\hline of species data: & 11.5 & 15.7 & \\
\hline of species-envir. relation: & 42.9 & 58.7 & \\
\hline Sum of all eigenvalues & & & 1.000 \\
\hline Sum of all canonical eigenva & alues & & 0.268 \\
\hline
\end{tabular}

Fig. 3 A Ordination biplot of redundancy analysis (RDA) for zooplankton communities (species) and hydrological and hydrochemical data (environmental variables) for floodplain lakes and the Biebrza River. Vectors pointing in the same direction indicate a positive correlation, vectors crossing at right angles indicate a near zero correlation, while vectors pointing in opposite direction show a high negative correlation. B Relative values of zooplankton communities (pies charts) in relation to the connectivity gradient between river channel and floodplain lake. C Relative values of zooplankton communities in pies charts in relation to high (HW), mean (MW) and low (LW) water levels. Abbreviations used in the figures: Acr_har, Acroperus harpae; Alo_rec, Alona rectangula; Anu_fis, Anuraeopsis fissa; Arc_dis, Arcella discoides; Arc_gib, Arcella gibbosa; Asc_sal, Ascomorpha saltans; Bra_ang, Brachionus

chlorophyll- $a$, TN, TP DOC, SEC, BGA and turbidity). The first axis (RDA1, horizontal) displayed a gradient of isolation of floodplain lakes and attributed to the SEC, turbidity and BGA, and to a lesser extent,

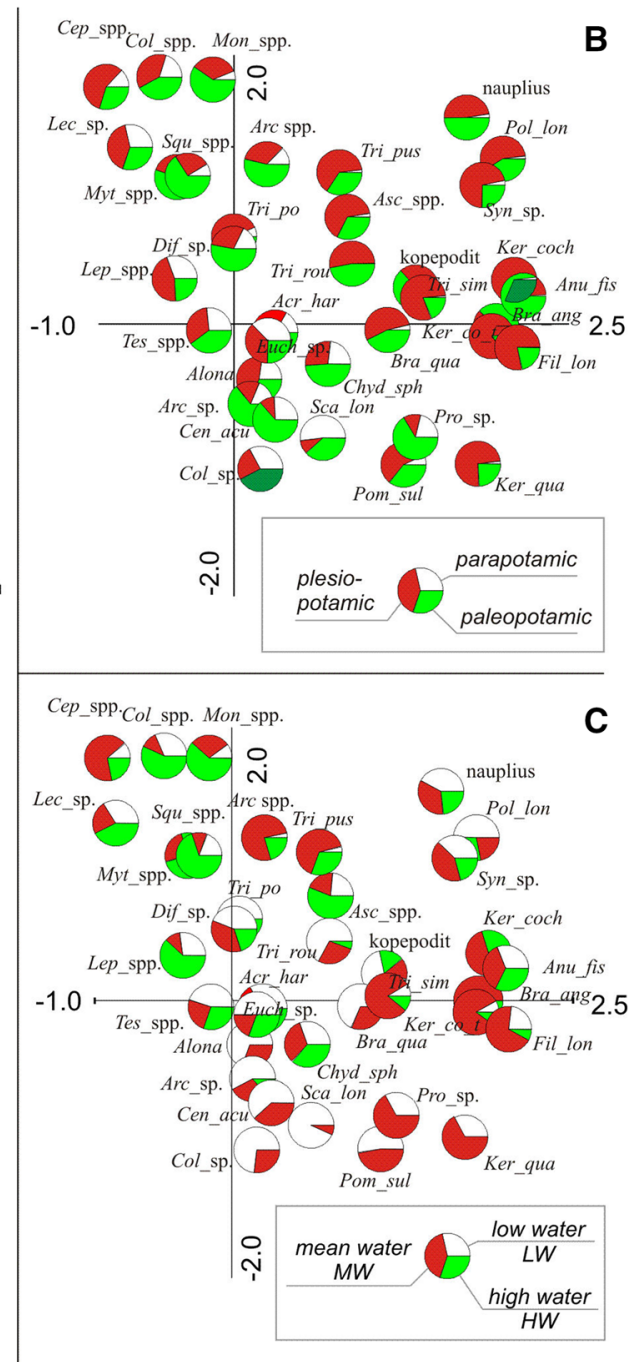

angularis; Bra_qua, Brachionus quadridentatus; Cen_acu, Centropyxis aculeata; Cep_sp., Cephalodella sp.; Chyd_sph, Chydorus sphaericus; Col_col, Colurella colurus; Col_unc, Colurella uncinata; Dif_spp., Difflugia spp.; Euch_dil, Euchlanis dilatata; Fil_lon, Filinia longiseta; Ker_coch, Keratella cochlearis; Ker-tec, Keratella cochlearis var. tecta; Ker_qua, Keratella quadrata; cop_cycl, copepodite of cyclopoids; Lec_spp., Lecane spp.; Lep_ova, Lepadella ovalis; Mon_mac, Monommata maculata; Myt_muc, Mytilina mucronata; nau_cycl, nauplii of cyclopoids; Pol_lon, Polyarthra longiremis; Pom_sul, Pompholyx sulcata; Pro_sp., Proales sp.; Sca_lon, Scaridium longicaudum; Squ_ros, Squatinella rostrum; Syn_sp., Synchaeta sp.; Tes_pat, Testudinella patina; Tri_pus, Trichocerca pusilla; Tri_rou, Trichocerca rousseleti; Tri_sim, Trichocerca similis; Tri_poc, Trichotria pocillum

to TP variables. The second axis (RDA2, vertical) represented water aeration and nitrate concentrations, which were negatively correlated with $\mathrm{COD}_{\mathrm{Cr}}$, chlorophyll- $a$ and TN variables (Fig. 3A). 
Table 4 Selected explanatory variables representing significant relations between the species and environmental data (marginal and conditional effects)

\begin{tabular}{|c|c|c|c|c|}
\hline \multirow[t]{2}{*}{ Variable } & \multirow{2}{*}{$\begin{array}{l}\text { Marginal effects } \\
\lambda^{\mathrm{a}} 1\end{array}$} & \multicolumn{3}{|c|}{ Conditional effects } \\
\hline & & $\lambda \mathrm{A}$ & $P$ value & $F$-ratio \\
\hline Hydrological connectivity ${ }^{\mathrm{b}}$ & 0.09 & 0.09 & 0.002 & 16.43 \\
\hline SEC & 0.07 & 0.06 & 0.002 & 13.57 \\
\hline Water level & 0.06 & 0.08 & 0.002 & 16.66 \\
\hline BGA & 0.05 & 0.03 & 0.002 & 6.90 \\
\hline $\mathrm{COD}_{\mathrm{Cr}}$ & 0.04 & 0.03 & 0.004 & 6.89 \\
\hline $\mathrm{NO}_{3}-\mathrm{N}$ & 0.04 & 0.02 & 0.004 & 4.75 \\
\hline $\mathrm{TN}$ & 0.04 & 0.01 & 0.018 & 2.60 \\
\hline Turbidity & 0.03 & 0.02 & 0.002 & 5.35 \\
\hline Chl_a & 0.02 & 0.01 & 0.008 & 3.62 \\
\hline DOC & 0.02 & 0.01 & 0.032 & 2.32 \\
\hline DO & 0.02 & 0.01 & 0.008 & 3.27 \\
\hline TP & 0.01 & 0.01 & 0.016 & 2.72 \\
\hline
\end{tabular}

${ }^{a}$ Lambda $(\lambda)$ denotes the amount of variability in the species data that would be explained by a constrained ordination model using that variable as the only explanatory variable. Variables not used in the table were statistically insignificant

${ }^{b}$ Hydrological connectivity measured as a gradient of lake isolation at mean water level

\section{Discussion}

The results of zooplankton analyses in floodplain lakes in the Middle Basin of the Biebrza River demonstrated that water retention time and hydrological conditions are major factors controlling the diversity and abundance of the group of invertebrates. Lateral connectivity of floodplain lakes along the Biebrza River was responsible for nutrient cycling and biodiversity, which is consistent with the hypothesis postulated by Amoros \& Bornette (2002). The qualitative structure of zooplankton of the studied floodplain lakes was based on a significant degree of the image of taxonomic composition of the Biebrza River waters. It was grounded on the Rotifera species abundance, being a characteristic feature of parapotamic ecosystems. This phenomenon is connected with the short generation cycle of this group and the possibility to satisfy the food requirements in scanty river waters (Baranyi et al., 2002). The qualitative structure of Rotifera was based mainly on pelagic species with a broad spectrum of tolerance to environmental conditions: A. fissa, K. cochlearis, K. cochlearis var. tecta, $B$. angularis, $P$. longiremis, $F$. longiseta, Trichocerca pusilla, $T$. similis and $T$. rousseleti. The density of their populations changed with the type of communication with the main river bed (Fig. 3B). The results presented in the present paper correspond to the results obtained by Schöll et al. (2012) in studies of meanders at various degrees of connectivity with Danube River and Gruberts et al. (2007) within the floodplain lakes of Daugava River (Latvia). However, a reciprocal dependence between the type of communication of meanders with the watercourse and species $\left(H^{\prime}, d, J^{\prime}\right)$ and environmental diversities of zooplankton was found.

Typical littoral genera of Cladocera (Alona, Acroperus, Camptocercus, Graptoleberis, Simocephalus, Eurycercus and Pleuroxus) have been frequently present, but scarcely, and their share in the biocoenosis was paradoxically higher in parapotamic meandering channels $(7.4 \%)$ than in paleopotamic ones $(2.3 \%)$. The very presence of organisms avoiding this factor in the midstream is probably a consequence of leaching action of flowing water (Havel et al., 2000). On the other hand, a small representation of crustaceans (apart from nauplii larvae), in the closed floodplain lakes (mean $5 \%$ in total), may result from the pressure of fishes. The paleopotamic floodplain lakes form a particular littoral on the entire bottom surface, and broad macrophyte zones constitute an additional refuge for Cladocera. 
They are breeding grounds, hatching grounds, and then refuges and feeding grounds for fish larvae (Meschiatti \& Arcifa, 2002; Iglesias et al., 2007), simultaneously. Zooplankton is the first type of external food for almost all fish species. Crustaceans and rotifers inhabiting the littoral zone, because of their larger sizes and energy value, are subject to the highest pressure from fish (Kerfoot \& Sih, 1987; Meschiatti et al., 2000; Pithart et al., 2007). Thus, their abundance and quantitative share in the total structure of zooplankton of the floodplain lakes with limited flow is low, in comparison with minute plankton species living in the water depth and in the midstream. The macrophyte zone, as a refuge, is consequently a compromise between gains and losses in the zooplankton biocoenosis (Hunt \& Matveev, 2005).

Many authors emphasise the influence of water level fluctuations on zooplankton communities in floodplain lakes. Studies carried out in floodplain water regions of the Daugava River, and Gruberts et al. (2007) showed an inverse and statistically significant correlation between the water level and the general abundance of zooplankton. Thereafter, Sampaio \& López (2000) emphasised the influence of high water levels of the Paraopeba River on the improvement of oxygen level in the floodplain lakes and an increase in the density and biodiversity of the Copepoda and Rotifera structure. Our studies showed that higher water levels favoured occurrence of a higher diversity of crustaceans and protozoans at the cost of a decrease in the rotifer share. In general, the best conditions for the zooplankton growth occurred in seasons with medium water levels, what supports the Connel's (1979) hypothesis of 'Intermediate Disturbance'.

The water level may also influence the direction and intensity of species interactions, for example, when the water level decreases and simultaneously, the area of fish penetration is being restricted, utilisation of zooplankton resources may be more complete. Diversity of plankton crustaceans ascertained in this paper in the paleopotamic floodplain lakes, particularly, that of Cladocera, may be explained by a low availability of these organisms for fish, juvenile stages (Sutela \& Huusko, 2000), or by the deterioration of physical conditions of water. A decrease in depth leads to a higher destabilisation of the water column, frequently connected with an increase in turbidity as a result of entertainment of the superficial layer of the benthic deposits. The increase in turbidity impairs visibility and the ability of fish to localise their prey (Kerfoot \& Sih, 1987), thus, improving the safety and refuge effectiveness of plankton fauna when hiding from predators (Špoljar et al., 2011).

Another direction of shaping the zooplankton structure is through the influence of variability of the physico-chemical parameters connected to the water level oscillations. When the water level is high, it is connected to a decrease in the contents of organic substances, including biogenic substances dissolved in the water, limiting the intensity of primary production. In consequence, food resources of plankton fauna are reduced. Many species withdraws from the ecosystem as a result of competition for food (Rotifera) or because of an inability to gather food effectively (Cladocera and Copepoda) (Schröder, 2001; Keppeler \& Hardy, 2004; Thomaz et al., 2007). Our observations proved a more abundant presence of Crustacea in the period of medium water level than that in low water level, corresponding to a higher concentration of food. On the other hand, a low water season in the situation of an increase in the biogen concentrations favoured the growth of Rotifera species, indicating a heightened trophy level, in paleopotamic and plesiopotamic floodplain lakes (Fig. 3C). A strong prevalence of one or several species preferring high biogen concentrations, often connected to a decrease in the dissolved oxygen contents, causes an elimination of many more sensitive taxa (Sampaio \& López, 2000). An influence of progressive eutrophication of paleopotamic floodplain lakes on depletion of the Crustacea structure has been discussed by many researchers, including Paganelli \& Sconfietti (2013) in a Topo lake on the Ticino River (Italy), as well as Illyová (2006) for the floodplain lakes along the Morava River (Slovakia). The Cladocera structure found in our study is based on the aforementioned "minute" species, and high abundance and share of Ch. sphaericus indicate its growth (Haberman \& Haldna, 2014).

The dependence of the increase in rotifer trophy indicators abundance (A. fissa, B. angularis, $F$. longiseta, K. cochlearis var. tecta, Trichocerca similis, T. rousseleti and P. longiremis) and Cladocera $C h$. sphaericus population with the increase in turbidity, presence of blue-green algae cells and dissolved organic matter has been confirmed by the results of the RDA analysis. These factors are positively 
correlated to the isolation, increase from the main river channel (Fig. 3A, B). Then, growth of psammonic, phytophilic taxa (Lecane sp., Lepadella ovalis, Cephalodella sp., Colurella uncinata and Mytilina mисronata) was related to water movement and, thus, well-aerated water, and increase in the water level (Fig. 3A-C). Also, the presence of Cladocera from Alona genera and protozoa is attributed to a good aeration of water.

Our results also confirmed direct correlations between physico-chemical parameters of water and zooplankton communities widely reported by aquatic ecologists. Gruberts et al. (2007) emphasised the influence of the concentration of the organic suspension on the number of zooplankton species, the influence of water temperature and dissolved oxygen content on the abundance of Cladocera, and the influence of $\mathrm{pH}$, the number of blue-green algae cells, the total phosphorus concentration of the biomass and abundance of Copepoda. Pithart et al. (2007) reported the relationship between the increases in $\mathrm{PO}_{4}-\mathrm{P}$ and $\mathrm{NH}_{4}-\mathrm{N}$ concentration, and the decrease in biomass and number of phytoplankton species, as well as the beneficial influence of these parameters on the presence of Cladocera. Moreover, the total abundance of zooplankton with conductivity, and the abundance of Rotifera with chlorophyll- $a$ was correlated. They also reported the relationship between the abundance of large Cladocera species with oxygen and $\mathrm{NO}_{3}-\mathrm{N}$ concentrations.

\section{Conclusion}

The stated differences in the zooplankton structure are due to some environmental factors, among which hydrological conditions are responsible for biodiversity gradients in the studied floodplain lakes. One of them is the disturbance of ecological balance in the ecosystem. In the analysed problem, the main disturbance is the lateral connectivity of floodplain lakes with river channel, on the background of which, competition and predation take place. The stated decrease in taxonomic diversity of plankton fauna in the paleopotamic and plesiopotamic water bodies resulted from excluding species of low competitiveness not adjusted to rare disturbances in stable eutrophicated habitats of the floodplain lakes.

Frequent changes related to a permanent flow of water in the parapotamic lakes, enable the development and high diversity of species of increased development rate (Rotifera). During the period of mean water levels, we observed the highest diversity of planktonic fauna in the studied floodplain lakes which corresponds to the 'intermediate disturbance hypothesis' of Connel (1979).

Based on the results achieved, we consider hydrological conditions in the Biebrza River floodplain, as a basic natural factor regulating plankton community structure in floodplain lakes. Apart from abiotic factors stated above, we cannot exclude the role of fish predation on zooplankton structure. Differences in habitat conditions between the river channel and floodplain lakes are some of the factors stimulating the diversity of plankton fauna.

Acknowledgments This study was supported financially by the National Science Center, grant no. NN304317440.

\section{Compliance with ethical standards}

Conflict of interest All of the authors read and approved the paper that has not been published previously nor is it being considered by any other peer-reviewed journal. The authors declare that there are no conflicts of interest.

Open Access This article is distributed under the terms of the Creative Commons Attribution 4.0 International License (http:// creativecommons.org/licenses/by/4.0/), which permits unrestricted use, distribution, and reproduction in any medium, provided you give appropriate credit to the original author(s) and the source, provide a link to the Creative Commons license, and indicate if changes were made.

\section{References}

Amoros, C. \& G. Bornette, 2002. Connectivity and biocomplexity in waterbodies of riverine floodplains. Freshwater Biology 47: 761-776.

Amoros, C. \& A. L. Roux, 1988. Interactions between water bodies within floodplains of large rivers: function and development of connectivity. Münstersche Geografische Arbeiten 29: 125-130.

APHA, 1999. Standard Methods for the Examination of Water and Wastewater, 20th ed. American Public Health Association, Washington, DC.

Baranyi, C., T. Hein, C. Holarek, S. Keckeis \& F. Schiemer, 2002. Zooplankton biomass and community structure in a Danube River floodplain system: effects of hydrology. Freshwater Biology 47: 473-482.

Bottrell, H. H., A. Duncan, Z. M. Gliwicz, E. Grygierek, A. Herzig, A. Hillbicht-Ilkowska, H. Kurasawa, P. Larsson \& T. Wegleńska, 1976. A review of some problems in zooplankton production studies. Norwegian Journal of Zoology 24: 419-456. 
Buijse, A. D., H. Coops, M. Staras, L. H. Jans, G. J. Van Geest, R. E. Grift, B. W. Ibelings, W. Oosterberg \& F. C. Roozen, 2002. Restoration strategies for river floodplains along large lowland rivers in Europe. Freshwater Biology 47(4): 889-907.

Braun-Blanquet, J., 1964. Plant Sociology. Basic Course of Vegetation Science. Pflanzensoziologie. Grundzuge der Vegetationskunde. Springer, New York.

Chormański, J., T. Okruszko, S. Ignar, O. Batelaan, K. T. Rebel $\&$ M. J. Wassen, 2011. Flood mapping with remote sensing and hydrochemistry: a new method to distinguish the origin of flood water during floods. Ecological Engineering 37: 1334-1349.

Connell, J. H., 1979. Intermediate-disturbance hypothesis. Science 204(4399): 1345.

Dembowska, E. A., 2015. Seasonal variation in phytoplankton and aquatic plants in floodplain lakes (lower Vistula River, Poland). Wetlands Ecology and Management 23: 535-549.

Duggan, I. C., 2001. The ecology of periphytic rotifers. Hydrobiologia 446(447): 139-148.

Dunalska, J. A., D. Górniak, B. Jaworska, E. Evelyn \& E. E. Gaiser, 2012. Effect of temperature on organic matter transformation in a different ambient nutrient availability. Ecological Engineering 49: 27-34.

Ejsmont-Karabin, J., 1998. Empirical equations for biomass calculation of planktonic rotifers. Polskie Archiwum Hydrobiologii 45: 513-522.

Grabowska, M., K. Glińska-Lewczuk, K. Obolewski, P. Burandt, J. Sz. Kobus, J. Dunalska, R. Kujawa, A. Goździejewska \& A. Skrzypczak, 2014. Effects of hydrological and physicochemical factors on phytoplankton communities in floodplain lakes. Polish Journal of Environmental Studies 23(3): 713-725.

Gruberts, D., I. Druvietis, E. Parele, J. Paidere, A. Poppels, J. Prieditis \& A. Skute, 2007. Impact of hydrology on aquatic communities of floodplain lakes along the Daugava River (Latvia). Hydrobiologia 548: 223-237.

Haberman, J. \& M. Haldna, 2014. Indices of zooplankton community as valuable tools in assessing the trophic state and water quality of eutrophic lakes: long term study of Lake Võrtsjärv. Journal of Limnology 73(2): 263-273.

Hammer, R., D. A. T. Harper \& P. D. Ryan, 2001. PAST: paleontological statistics software package for education and data analysis. Palaeontologia Electronica 4(1): 9.

Havel, J. E., M. Eisenbacher \& A. A. Black, 2000. Diversity of crustacean zooplankton in riparian wetlands: colonization and egg banks. Aquatic Ecology 34: 63-76.

Hunt, R. J. \& V. F. Matveev, 2005. The effects of nutrients and zooplankton community structure on phytoplankton growth in a subtropical Australian reservoir: an enclosure study. Limnologica 35: 90-101.

Iglesias, C., G. Goyenola, N. Mazzeo, M. Meerhoff, E. Rodo \& E. Jeppesen, 2007. Horizontal dynamics of zooplankton in subtropical Lake Blanca (Uruguay) hosting multiple zooplankton predators and aquatic plant refuges. Hydrobiologia 584(1): 179-189.

Illyová, M., 2006. Zooplankton of two arms in the Morava River floodplain in Slovakia. Biologia, Bratislava 61(5): 531-539.

Karabin, A., 1985. Pelagic zooplankton (Rotatoria + Crustacea) variation in the process of lake eutrophication.
I. Structural and quantitative features. Ekologia Polska 33: 567-616.

Kasprzak, K. \& W. Niedbała, 1981. Biocenotic indices in quantitative study. In Górny, M. \& L. Grüm (eds), Methods Applied in Soil Zoology. PWN, Warsaw: 396-416.

Keppeler, E. C. \& E. R. Hardy, 2004. Abundance and composition of Rotifera in an abandoned meander lake (Lago Amapá) in Rio Branco, Acre, Brazil. Revista Brasileira de Zoologia 21(2): 233-241.

Kerfoot, W. C. \& A. Sih, 1987. Predation. Direct and Indirect Impacts on Aquatic Communities. University Press of New England, Hanover: 149-160.

Kiefer, F., \& G. Fryer. 1978. Das Zooplankton der Binnengewässer. Teil 2. E. Schweizerbartsche Verlag, Stuttgart: $380 \mathrm{pp}$.

Koste, W., 1978. Rotatoria. Die Rädertiere Mitteleuropas. Gebrüder Borntraeger, Berlin.

Kufel, L. \& S. Lesniczuk, 2014. Hydrological connectivity as most probable key driver of chlorophyll and nutrients in oxbow lakes of the Bug River (Poland). Limnologica 46: 94-98.

Medeiros, E. S. F. \& A. Arthington, 2008. The importance of zooplankton in the diets of three native fish species in floodplain waterholes of a dryland river, the Macintyre River, Australia. Hydrobiologia 614: 19-31.

Meschiatti, A. J. \& M. S. Arcifa, 2002. Early live stages of fish and the relationships with zooplankton in a tropical Brazilian reservoir: Lake Monte Alegre. Brazilian Journal of Biology 62(1): 41-50.

Meschiatti, A. J., M. S. Arcifa \& N. Fenerich-Verani, 2000. Fish communities associated with macrophytes in Brazilian floodplain lakes. Environ Biol Fishes 58: 133-143.

Paganelli, D. \& R. Sconfietti, 2013. Biodiversity loss in a small riverine wetland of the Ticino river (Lombardia, Northern Italy). Journal of Limnology 72(3): 573-581.

Pithart, D., R. Pilchová, J. Bílý, J. Hrabáček, K. Novotná \& L. Pechar, 2007. Spatial and temporal diversity of small shallow waters in river Lužnice floodplain. Hydrobiologia 548: 265-275.

Pociecha, A. \& E. Wilk-Woźniak, 2006. The life strategy and dynamics of selected species of phyto- and zooplankton in a dam reservoir during "wet" and "dry" years. Polish Journal of Ecology 54(1): 29-38.

Radwan, S. \& I. Bielańska-Grajner, 2001. Ecological structure of psammonic rotifers in the ecotonal zone of Lake Piaseczno (eastern Poland). Hydrobiologia 446/447(1): 221-228.

Radwan, S., I. Bielańska-Grajner \& J. Ejsmont-Karabin, 2004. Fauna słodkowodna Polski. Wrotki. Zeszyt 32A and 32B.Wyd. Oficyna Wydawnicza Tercja: 1-447.

Ruttner-Kolisko, A., 1977. Suggestions for biomass calculations of plankton rotifers. Archiv für Hydrobiologie-Beiheft Ergebnisse der Limnologie 8: 71-76.

Rybak, J. I. \& L. A. Błędzki, 2010. Słodkowodne skorupiaki planktonowe (in Polish: Freshwater Planktonic Crustaceans). Warsaw University Press, Warsaw.

Sampaio, E. V. \& C. M. López, 2000. Zooplankton community composition and some limnological aspects of an oxbow lake of the Paraopeba River, São Francisco River Basin, Minas Gerais, Brazil. Brazilian Archives of Biology and Technology 43(3): 285-293. 
Schöll, K., A. Kiss, M. Dinka \& A. Berczik, 2012. Flood-pulse effects on zooplankton assemblages in a river floodplain system (Gemenc Floodplain of the Danube, Hungary). International Review of Hydrobiology 97(1): 41-54.

Schröder, T., 2001. Colonising strategies and diapause of planktonic rotifers (Monogononta, Rotifera) during aquatic and terrestrial phases in a floodplain (Lower Oder Valley, Germany). International Review of Hydrobiology 86(6): 635-660.

Sterble, H. \& D. Krauter, 1978. Das Leben im Wassertropfen. Mikroflora und mikrofauna des Süßwassers. Kosmos: 5-336.

Sutela, T. \& A. Huusko, 2000. Varying resistance of zooplankton prey to digestion: implication for quantifying larval fish diets. Transaction of the American Fisheries Society 129(2): 545-551.

Špoljar, M., T. Dražina, I. Habdija, M. Meseljević \& Z. Grjčić, 2011. Contrasting zooplankton assemblages in two oxbow lakes with low transparencies and narrow emergent macrophyte belts (Krapina River, Croatia). International Review of Hydrobiology 96(2): 175-190.
Thomaz, S. M., L. M. Bini \& R. L. Bozelli, 2007. Floods increase similarity among aquatic habitats in river-floodplain systems. Hydrobiologia 579: 1-13.

ter Braak, C. J. F., \& P. Šmilauer, 2002. Reference manual and CanoDraw for Windows User's guide: Software for Canonical Community Ordination (version 4.5) - Microcomputer Power (Ithaca, NY, USA), 500 pp.

von Flössner, D., 1972. Krebstiere, Crustacea. Kiemen- und Blattfüsser, Branchiopoda, Fischläuse, Branchiura. VEB Gustav Fischer Verlag, Jena.

Wassen, M. J., W. H. M. Peeters \& H. O. Veneterink, 2002. Patterns in vegetation, hydrology and nutrient availability in an undisturbed river floodplain in Poland. Plant Ecology 165: $27-43$.

Winemiller, K. O., S. Tarim, D. Shormann \& J. B. Cotner, 2000. Fish assemblage structure in relation to environmental variation among Brazos River oxbow lakes. Transactions of American Fisheries Society 129: 451-468. 